\title{
Pengelolaan Anggaran Pendapatan dan Belanja Negara (APBN) sebagai Piranti Fiskal dalam Pembangunan Ekonomi Indonesia
}

\author{
Marwanto
}

APBN, Kebijaksanaan Fiskal, dan Perundangan yang melandasinya. nggaran Pendapatan dan A Belanja Negara (APBN) pada hakekatnya merupakan ringkasan dari semua jenis penerimaan dan pengeluaran negara yang akan diterima dan dibelanjakan dalam satu tahun tertentu". Dalam bentuk sebuah rencana, maka pada awal tahun anggaran, berbagai angka yang tercantum tersebut merupakan sebuah perkiraan atas penerimaan yang akan diterima dan suatu janji untuk mengeluarkan sejumlah uang tertentu untuk membiayai pelaksanaan pemerintahan dan pembangunan pada tahun tersebut. Dengan demikian merupakan suatu konsekuensi logis bila dikatakan bahwa terpenuhinya janji untuk membiayai berbagai kegiatan pemerintahan tersebut sangat tergantung kepada keberhasilan pengumpulan penerimaan negara yang direncanakan. Apabila dalam satu tahun tertentu pemerintah tidak berhasil memenuhi sasaran penerimaan yang direncanakan tanpa upaya sumber lain -, maka sebagai akibatnya pasti ada beberapa kegiatan yang tidak dapat (kurang) pembiayaannya.

Di Indonesia, APBN telah digunakan sebagai piranti fiskal yang efektif terutama sejak masa Orde Baru. Namun demikian, bukan berarti bahwa keefektifannya kemudian tanpa hambatan. Seperti diketahui, pengelolaan anggaran yang berimbang dan dinamis, telah diakui banyak pihak telah membawa kondisi perekonomian Indonesia menuju kepada berbagai kemajuan. Tentu saja tidak dapat dipungkiri bahwa prestasi tersebut bukan hanya merupakan peran pengelolaan budget semata-mata, tetapi merupakan sinergi dan kebijaksanaan di bidang moneter (Monetary Policy), neraca pembayaran dan perdagangan luar negeri (External Policy), dan kebijaksanaan fiskal (Fiscal Policy).

Meskipun bukan merupakan satusatunya kebijaksanaan yang diluncurkan pada masa awal Orde Baru, tetapi sebagai sebuah paket pengelolaan kebijaksanaan ekonomi makro, pengelolaan APBN pada saat itu terbukti telah mampu mengendalikan kondisi perekonomian pada tingkat yang stabil. Salah satu kunci pengelolaan anggaran yang dianggap banyak pihak merupakan terapi yang mujarab untuk "menenteramkan" keadaan

1) Di beberapa negara, budget belum menggambarkan totalitas penerimaan dan pengeluaran negara, mengingat ada beberapa jenis penerimaan dan pengeluaran negara yang berasal dari sumber non-budget (extra budgetary account) 
ekonomi pada saat itu adalah dengan diterapkannya anggaran yang berimbang, dan ditinggalkannya kebijaksanaan defisit anggaran yang dibiayai dengan pencetakan uang baru. Kebijaksanaan ini paling tidak telah mampu meredam laju inflasi yang semula mencapai tingkat yang sangat tinggi, yakni sekitar 650 persen pada tahun 1966 menjadi sekitar 9,89 persen dalam tahun 1969, kemudian 21,77 persen dalam tahun 1979, dan sejak Pelita IV inflasi telah dapat dikendalikan pada tingkat satu digit (kecuali tahun 1992/1993 inflasi sebesar 10,03 persen).

Dengan bukti sejarah tersebut, tidaklah berlebihan kalau para ahli (termasuk juga politician) kemudian berpendapat bahwa APBN sebagai suatu piranti fiscal, bukan saja merupakan suatu kebijaksanaan yang menyelamatkan kondisi perekonomian, tetapi merupakan suatu piranti ekonomi yang bermakna politik. Oleh sebab itu tidaklah berlebihan apabila seorang ekonom, politisi, yang sekaligus mantan anggota Kabinet, Frans Seda, mengemukakan bahwa adalah merupakan pembahasan yang kurang memadai bila APBN nya disoroti dari sisi budget-teknis yang berdampak ekonomi teknis's). Bukan saja karena secara yuridis APBN diatur dalam UUD 1945, tetapi lebih dari itu karena secara prosedural mekanisme penyusunannya melalui persetujuan wakil-wakil rakyat di DPR. Dengan demikian dapat dimengerti apabila APBN adalah bukan semata-mata produk ekonomi, yang didalamnya termuat nuansa politik yang hendak dicapai, tetapi juga menggambarkan bagaimana masalah yang berkaitan dengan politik dapat diselesaikan secara ekonomi (efisien).

APBN merupakan salah satu piranti kebijaksanaan fiskal. Kebijaksanaan fiskal (fiscal policy) diterjemahkan sebagai segenap kebijaksanaan yang menyangkut pengelolaan penerimaan dan pengeluaran negara yang dilakukan oleh pemerintah suatu negara ${ }^{3}$. Dengan demikian melalui kebijaksanaan ini, pemerintah dapat bertindak sebagai "pemandu" yang berkuasa yang dapat mengarahkan perekonomian pada tingkat yang efisien. Untuk itu, ada tiga peran penting yang dapat dilakukan oleh pemerintah untuk mengendalikan perekonomian menuju arah yang benar, yakni peran alokasi, peran distribusi, dan peran stabilisasi.

Peran alokasi menjadi sangat diperlukan dalam menciptakan alokasi sumber ekonomi sehingga tercapai alokasi yang efisien. Fungsi ini makin penting karena dalam kenyataannya mekanisme pasar tidak selalu mampu menyediakan barang-barang publik yang pemanfaatannya oleh masyarakat tidak dapat diselesaikan dengan cara-cara ekonomi. Di samping itu, kegagalan pasar (market failure) juga menyebabkan tidak dapat terpenuhinya barang/jasa tertentu disediakan oleh pasar. Fenomena ini menunjukkan bahwa peranan pemerintah dalam perekonomian tersebut juga dalam rangka menggantikan ketidakmampuan pasar dalam memecahkan masalahmasalah ekonomi secara tuntas.

Peran distribusi juga diperlukan karena dalam suatu pembangunan ekonomi, mekanisme pasar dalam banyak kasus cenderung menciptakan distribusi pendapatan yang seringkali dirasakan tidak adil. Seperti diketahui, distribusi pendapatan bentuknya akan dapat dipengaruhi oleh beberapa faktor, diantaranya pemilikan faktor produksi oleh masyarakat, tarik menarik antara permintaan dan penawaran faktor produksi, serta aturan-aturan lalu yang berlaku di dalam masyarakat itu (misalnya sistem warisan) ${ }^{4}$. Dengan demikian,

2) Frans Seda, Kekuasaan dan Moral, PT. Gramedia, 1996, hal 347

3) Lihat lebih lanjut pada buku Musgrave and Musgrave, Public Finance in Theory and Practice, Mc. Grow-Hill 1984.

4) Guritno Mangkoesoebroto, Kebijaksanaan Ekonomidi Indonesia, PT. Gramedia, 1994, halaman 7 
konsentrasi pemilikan faktor-faktor produksi dan teknik produksi yang digunakan dalam proses produksi, akan sangat menentukan aliran pendapatan kepada pemilik faktor produksi.

Peranan pemerintah dalam mengendalikan kestabilan ekonomi diperlukan, karena gangguan atas satu sektor ekonomi, pada gilirannya akan terkait dengan sektor-sektor yang lain. Penurunan atas permintaan suatu produk (rokok misalnya), akan membawa pengaruh terhadap turunnya keuntungan perusahaan, yang ada gilirannya bila keadaan terus berlangsung merupakan potensi untuk meningkatkan pengangguran. Pada putaran berikutnya, karyawan yang menganggur akan mengurangi permintaan atas barangbarang konsumsinya seperti pakaian, perumahan, dan barang-barang lainnya. $\mathrm{Hal}$ ini bila berlangsung lama akan sangat mengganggu pertumbuhan ekonomi. Di samping itu, fungsi penting lainnya dalam mewujudkan stabilisasi adalah mengendalikan harga (inflasi). Pengendalian tingkat harga merupakan masalah yang erat hubungannya dengan pembangunan ekonomi secara makro. Inflasi yang terkendali merupakan salah satu faktor yang memberikan insentif pada pengusaha untuk melakukan investasi. Sebaliknya inflasi yang sangat berat (hyper inflation) akan mengakibatkan rusaknya tatanan dalam mekanisme perekonomian suatu negara.

Di Indonesia pengertian kebijaksanaan fiskal dalam arti luas secara yuridis formal dijelaskan dalam UUD Tahun 1945. Di dalam pasal 23 UUD 1945 beserta peraturan perundangan pelaksanaannya (Undang-undang tentang APBN), disebutkan secara jelas bahwa dalam rangka melaksanakan kebijaksanaan keuangan negara pemerintah menetapkan berbagai kebijaksanaan yang menyangkut APBN, Perkreditan, lalu lintas pembayaran luar negeri, serta pasar uang dan modal. Kebijaksanaan tersebut kemudian dijabarkan ke dalam kebijaksanaan jangka panjag dan menengah di dalam GBHN, yang umumnya merupakan sasaransasaran yang bersifat kualitatif. Dalam jangka menengah (5 tahun), maka kebijaksanaan di bidang fiskal dalam GBHN tersebut diterjemahkan ke dalam angka-angka konkrit di dalam setiap Repelita. Operasionalisasi tahunan dari setiap Repelita tersebut kemudian dijabarkan setiap tahun dalam APBN.

\section{Struktur dan Anatomi APBN}

Secara singkat, APBN terbagi menjadi 2 bagian kelompok besar, yaitu anggaran pendapatan negara dan anggaran belanja negara. Anggaran pendapatan negara merupakan sasaran penerimaan negara yang diharapkan dapat dihimpun dalam tahun anggaran bersangkutan, yaitu meliputi berbagai jenis pendapatan dalam negeri, serta pendapatan negara yang bersumber dari bantuan luar negeri. Sedangkan anggaran belanja negara, selain dipergunakan untuk pembayaran pengeluaran rutin guna mendukung pelaksanaan penyelenggaraan pemerintahan yang dituangkan ke dalam berbagai jenis program dan kegiatan serta pemenuhan berbagai kewajiban pemerintah, juga dipergunakan untuk belanja pembangunan yang dituangkan dalam berbagai jenis program dan proyek pembangunan pada berbagai sektor dan subsektor. Gambaran lebih rinci tentang struktur APBN dapat diikuti dalam Tabel I, yang memuat APBN tahun anggaran 1996/1997.

Berdasarkan sumber dan tujuan penggunaannya, pendapatan negara digolongkan ke dalam 2 (dua) kelompok utama, yaitu penerimaan dalam negeri dan penerimaan pembangunan. Penerimaan dalam negeri adalah penerimaan yang berasal dari sektor perpajakan dan sektor bukan pajak. Sedangkan penerimaan pembangunan adalah penerimaan yang berasal dari berbagai jenis bantuan luar negeri, baik yang berbentuk pinjaman 
maupun hibah, yang penggunaannya hanya ditujukan bagi pembiayaan pembangunan. Sejalan dengan pelaksanaan reformasi undang-undang perpajakan yang diberlakukan sejak awal Repelita IV (tahun anggaran 1984/1985), penerimaan dalam negeri yang semula diklasifikasikan dalam penerimaan pajak langsung, penerimaan pajak tidak langsung, dan penerimaan bukan pajak, diubah menjadi penerimaan minyak bumi dan gas alam (migas) dan penerimaan di luar minyak bumi dan gas alam (non migas). Perubahan ini dimaksudkan untuk memberikan penekanan terhadap peranana sektor nonmigas sebagai sumber penerimaan negara, yang harus semakin meningkat peranannya dalam pembiayaan pembangunan nasional. Sebagai sumber pembiayaan pembangunan, penerimaan nonmigas memiliki sifat yang lebih stabil dan lestari, karena lebih bersumber dari pembiayaan internal yang tidak terlalu peka terhadap gejolak perkembangan eksternal sebagaimana yang dialami penerimaan migas.

Penerimaan migas merupakan komponen (single item) yang cukup besar dalam penerimaan dalam negeri. Penerimaan migas adalah penerimaan yang berasal dari pajak penghasilan minyak bumi dan gas alam dan hasil-hasil minyak lainnya, yaitu bagian pemerintah atas minyak bumi dan gas alam, baik dalam rangka kontrak kerja (contract of work) maupun dalam rangka kontrak bagi hasil (production sharing).

Penerimaan di luar minyak bumi dan gas alam, terdiri dari seluruh penerimaan yang diperoleh dari penerimaan sektor perpajakan serta penerimaan di luar pajak. Penerimaan perpajakan antara lain terdiri dari pajak penghasilan (PPh), pajak pertambahan nilai barang dan jasa, dan pajak atas penjualan barang mewah (PPN dan PPN-BM), pajak bumi dan bangunan (PBB), bea masuk, cukai, pajak ekspor, dan pajak lainnya. Sedangkan penerimaan bukan pajak adalah penerimaan yang bersumber dari penerimaan berbagai departemen, antara lain penerimaan bukan pajak luar negeri, penerimaan pendidikan, penerimaan penjualan, penerimaan sewa dan jasa, penerimaan peradilan dan kejaksaan, penerimaan kembali pinjaman, serta penerimaan kembali dan lain-lain. Selain daripada itu, sebagai pemegang saham badan usaha milik negara (BUMN), Pemerintah juga menerima bagian pemerintah atas laba BUMN (termasuk bank-bank pemerintah). Jenis penerimaan ini juga merupakan komponen penerimaan bukan pajak yang cukup dominan.

Penerimaan pembangunan merupakan nilai lawan dari penerimaan negara yang berasal dari sumber-sumber luar negeri, baik berupa pinjaman maupun hibah (grant). Penerimaan tersebut dibagi menjadi bantuan program dan bantuan proyek. Bantuan program adalah nilai lawan bantuan teknis dan atau bantuan lainnya yang dirupiahkan, yaitu terdiri dari bantuan program murni, serta bantuan luar negeri yang dirupiahkan baik berupa bantuan khusus (special assistance) maupun bantuan yang segera dapat dirupiahkan (fast disbursing loan). Sejak tahun 1993/1994 dalam APBN sudah tidak diterima bantuan program ini. Sedangkan bantuan proyek adalah nilai rupiah dari bantuan luar negeri yang dipergunakan untuk mengimpor berbagai peralatan proyek dan membayar pelaksanaan proyek.

Belanja negara juga dibagi menjadi 2 (dua) kelompok utama yaitu pengeluaran rutin dan pengeluaran pembangunan. Pengeluaran rutin merupakan jenis pembiayaan negara yang disediakan untuk mendukung pembiayaan berbagai transaksi yang bersifat lancar dan terusmenerus, seperti kegiatan pembinaan, pemeliharaan, bimbingan, serta berbagai jenis kegiatan lainnya yang berkaitan dengan tugas-tugas pemerintahan dan pembangunan nasional. Pembiayaan tersebut dialokasikan kepada seluruh departemen/lembaga nondepartemen, 
dalam rangka penyelenggaraan berbagai kegiatan yang berkaitan dengan pelaksanaan tugas pemerintahan dan tugas pembangunan, baik pelaksanaan tugas administratif maupun pelayanan kepada masyarakat. Pengeluaran rutin terdiri dari belanja pegawai, belanja barang, subsidi daerah otonom, bunga dan cicilan hutang, serta pengeluaran rutin lainnya.

Pengeluaran pembangunan adalah pengeluaran yang digunakan untuk membiayai investasi yang produktif yang dilaksanakan Pemerintah, baik pembangunan sarana dan prasarana baru, maupun untuk rehabilitasi dan pemeliharaan berbagai sarana dan prasarana produktif yang telah ada. Secara fungsional pengeluaran pembangunan dikelompokkan menjadi pembiayaan rupiah murni dan pembiayaan bantuan proyek. Pembiayaan rupiah adalah pengeluaran pembangunan berasal dari tabungan pemerintah dan nilai rupiah bantuan program. Pembiayaan tersebut dikelompokkan menjadi pembiayaan bagi departemen/lembaga, pembiayaan pembangunan daerah, dan pengeluaran pembangunan lainnya. Pembiayaan departemen/lembaga menampung pembiayaan pembangunan yang penyediaan dananya dituangkan dalam DIP, dan pelaksanaannya menjadi tanggung jawab masing-masing departemen/lembaga. Pembiayaan pembangunan daerah digunakan untuk membiayai proyek-proyek pembangunan yang tercakup dalam berbagai program inpres, serta pembiayaan yang bersumber dari dana pajak bumi dan bangunan (PBB). Sedangkan pengeluaran pembangunan lainnya menampung berbagai jenis pembiayaan yang karena sifatnya tidak dapat ditampung di dalam DIP departemen/lembaga, atau pembiayaan pembangunan daerah. Pembiayaan tersebut antara lain terdiri dari subsidi pupuk, penyertaan modal pemerintah dan lain-lain pengeluaran pembangunan.
Beberapa Kebijaksanaan Penting Dalam Pengeiolaan APBN.

Sejak Repelita I, kebijaksanaan fiskal senantiasa didasarkan atas prinsip anggaran berimbang dan dinamis. Berimbang dalam arti jumlah keseluruhan pengeluaran (rutin dan pembangunan) selalu sama dengan jumlah keseluruhan penerimaan (dalam negeri dan pembangunan). Dinamis berarti dalam hal penerimaan lebih rendah dari yang direncanakan semula, pemerintah akan mengurangi.pengeluaran agar tetap terjaga keseimbangan. Demikian pula dalam hal penerimaan melampaui rencana semula, pemerintah akan meningkatkan pengeluaran agar keseimbangan tetap. terjaga. Dalam Repelita VI (GBHN 1993). kebijaksanaan fiskal tetap didasarkan pada prinsip anggaran berimbang yang dinamis dengan memungkinkan dibentuknya dana cadangan tersebut pada masa penerimaan negara tersebut kurang dari yang direncanakan atau tidak cukup mendukung program yang telah direncanakan dan/atau yang sangat mendesak sehingga terjamin kesinambungan pembiayaan yang diiringi oleh stabilitas ekonomi yang mantap.

Tabungan pemerintah yang merupakan selisih antara penerimaan dalam negeri dan pengeluaran rutin, diusahakan semakin besar. Peningkatan tabungan pemerintah tersebut diusahakan dengan meningkatkan penerimaan dalam negeridan melakukan penghematan dalam pengeluaran rutin, tanpa mengabaikan peningkatan kesejahteraan pegawai negeri dan tetap meningkatkan mutu pelayanan aparat pemerintah kepada masyarakat.

Kebijaksanaan di bidang penerimaan dalam negeri diusahakan agar terutama bersumber dari dalam negeri, oleh karena sumber dari luar negeri lebih dipengaruhi oleh faktor-faktor eksternal dan cenderung mengurangi kemandirian dalam pembiayaan pembangunan. Untuk itu, upaya peningkatan penerimaan dari dalam negeri yang bersumber dari perpajakan selalu diusahakan. 
Kebijaksanaan di bidang pengeluaran, khususnya pengeluaran rutin dilaksanakan dengan selalu didasarkan kepada prinsip efisiensi dan usaha-usaha penghematan, yang dilakukan tanpa mengabaikan perlunya dukungan yang memadai bagi kesejahteraan aparatur, serta cukupnya biaya bagi operasional serta pemeliharaan hasil-hasil pembangunan. Selain daripada itu, sejauh mungkin dikuranginya pemberian subsidi (harga), karena dapat menyebabkan alokasi sumber-sumber ekonomi yang tidak efisien, serta adanya kenyataan yang menunjukkan bahwa penerimaan akhir daripada subsidi tersebut sering bukan golongan yang diinginkan semula.

Kebijaksanaan di bidang pengeluaran pembangunan senantiasa didasarkan atas rencana proyek sektoral dan regional, yang pada gilirannya mengacu kepada rencana dan prioritas yang telah ditetapkan dalam Repelita. Pemilihan proyek-proyek pembangunan yang dituangkan dalam daftar isian proyek (DIP) didasarkan kepada azas-azas efisiensi dan efektifitas. Sedangkan pemilihan proyek-proyek dalam sektor dan subsektor ditetapkan dengan prioritas yang tinggi, produktif, menunjang pemerataan, serta mampu menciptakan lapangan kerja.

Bantuan luar negeri selalu berpedoman kepada GBHN, yang menekankan bahwa sumber dana untuk pembiayaan pembangunan terutama digali dari dalam negeri berdasarkan kemampuan sendiri. Sumber pembiayaan pembangunan dari luar negeri masih tetap diperlukan sebagai pelengkap, dengan ketentuan bahwa harus bersyarat lunak, tidak memberatkan dan tanpa ikatan politik. Di samping itu, bantuan luar negeri tersebut harus dapat digunakan untuk mendorong kegiatan pembangunan yang produktif, memberikan manfaat sebesar-besarnya bagi kesejahteraan rakyat, serta perannya pada dana pembangunan secara keseluruhan harus dikurangi secara bertahap.

\section{Daftar Pustaka}

Departemen Keuangan Republik Indonesia, Nota Keuangan dan RAPBN, beberapa penerbitan.

Frans Seda, Kekuasaan dan Moral, PT Gramedia, 1996.

Guritno Mangkoesoebroto, Kebijaksanaan Ekonomi Publik di Indonesia, PT Gramedia, 1996.

Garis-garis Besar Haluan Negara (GBHN), 1993.

Musgrave and Musgrave, Public Finance in Theory and Practice, MC GrowHill, 1984.

Premchad, Government Budgeting and Expenditure Controls, IMF, 1983. 
Tabel 1

APBN T/P 1995/1996 DAN APBN 1996/1997

(dalam miliar rupiah)

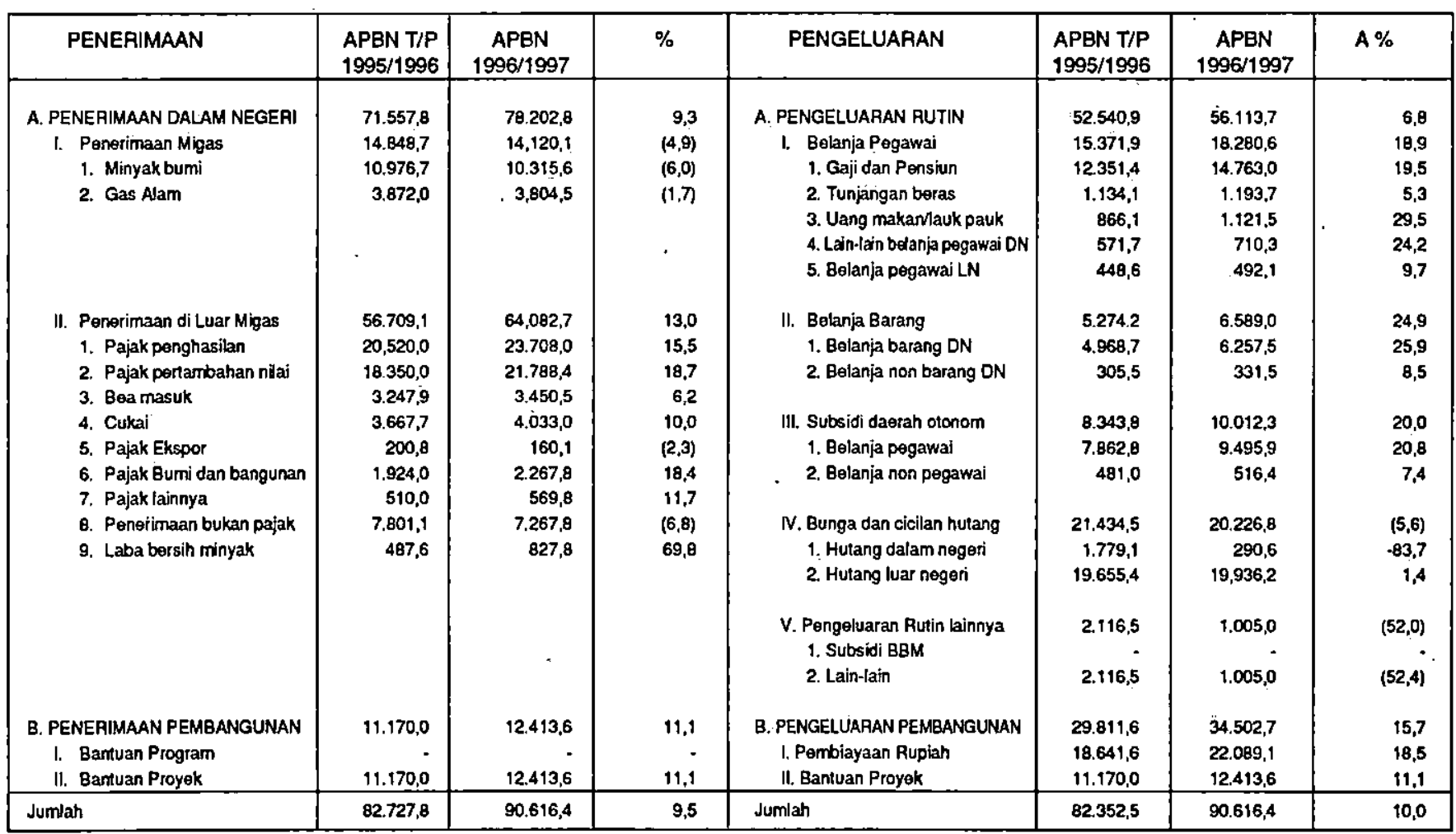

Tabungan Pemerintah:

APBN T/P 1995/1996: Ap. 19.016,9 miliar

APBN 1996/1997 : Rp. 22.089.1 miliar 
Tabel 2

Penerimaan Dalam Negerl, 1989/1990 - 1996/1997 (dalam niliar rupiah)

\begin{tabular}{|c|c|c|c|c|c|c|}
\hline \multirow{2}{*}{$\begin{array}{c}\text { Tahun } \\
\text { Anggaran }\end{array}$} & \multicolumn{2}{|c|}{$\begin{array}{c}\text { Penerimaan } \\
\text { minyak bumi dan } \\
\text { gas alam } \\
\end{array}$} & \multicolumn{2}{|c|}{$\begin{array}{c}\text { Penerimaan di } \\
\text { luar'minyak bumi } \\
\text { dan gas alam }\end{array}$} & \multicolumn{2}{|c|}{ Jumlah } \\
\hline & Nilai & (\%) & Nilaj & $(\%)$ & Nilai & $(\%)$ \\
\hline (1) & (2) & (3) & (4) & (5) & (6) & (7) \\
\hline Repelita V & & & & & & \\
\hline $1989 / 1990$ & $13.381,3$ & 42,5 & $18.122,9$ & 57,5 & $31.504,2$ & 100,0 \\
\hline $1990 / 1991$ & $17.740,0$ & 42,0 & $24.453,0$ & 58,0 & 42.193, & 100,0 \\
\hline $1991 / 1992$ & $15.069,6$ & 35,4 & $27.512,4$ & 65,6 & $42.582,0$ & 100,0 \\
\hline $1992 / 1993$ & $15.330,8$ & 31,4 & $33.531,8$ & 68,6 & $48.862,6$ & 100,0 \\
\hline 1993/1994 & $12.503,4$ & 22,3 & $43.609,7$ & 77,7 & $56.113,1$ & 100,0 \\
\hline Repelita VI & & & & & & \\
\hline $\begin{array}{l}1994 / 1995 \\
\text { (APBN T/P) }\end{array}$ & $13.399,2$ & 21,8 & $4.970,7$ & 78,2 & $61.369,9$ & 100,0 \\
\hline $\begin{array}{l}\text { 1995/1996 } \\
\text { (APBN T/P) }\end{array}$ & $14.848,7$ & 20,8 & $56.709,1$ & 79,2 & $71.557,8$ & 100,0 \\
\hline $\begin{array}{l}\text { 1996/1997 } \\
\text { (APBN) }\end{array}$ & $14.120,1$ & 18,1 & $64.082,7$ & 81,9 & $78.202,8$ & 100,0 \\
\hline
\end{tabular}


Tabel 3

Perkembangan Beberapa Jenis

Penerimaan Dalam Negerl, 1989/1990 - 1996/1997

(dalam nillar ruplah)

\begin{tabular}{|l|c|c|c|c|c|}
\hline \multicolumn{1}{|c|}{$\begin{array}{c}\text { Tahun } \\
\text { Anggaran }\end{array}$} & PPh & PPN & $\begin{array}{c}\text { Bea } \\
\text { masuk }\end{array}$ & Cukai & PBB \\
\hline (1) & $(2)$ & $(3)$ & $(4)$ & $(5)$ & $(6)$ \\
\hline Repelita V & & & & & \\
$1989 / 1990$ & $5.754,8$ & $5.986,1$ & $1.892,2$ & $1.482,2$ & 604,4 \\
$1990 / 1991$ & $8.250,0$ & $8.119,2$ & $2.799,8$ & $1.799,8$ & 785,8 \\
$1991 / 1992$ & $9.727,0$ & $9.145,9$ & $2.871,1$ & $1.915,0$ & 944,4 \\
$1992 / 1993$ & $12.516,3$ & $10.742,3$ & $3.223,3$ & $2.241,6$ & $1.106,8$ \\
$1993 / 1994$ & $14.758,9$ & $13.943,5$ & $3.555,3$ & $2.625,8$ & $1.484,5$ \\
Repellta VI & & & & & \\
$1994 / 1995$ & & & & & \\
(APBN T/P) & $18.350,1$ & $14.086,8$ & $3.218,0$ & $3.000,9$ & $1.632,1$ \\
$1995 / 1996$ & & & & & \\
(APBN T/P) & $20.520,0$ & $18.350,0$ & $3.247,9$ & $3.667,7$ & $1.924,0$ \\
$1996 / 1997$ & & & & & \\
(APBN) & $23.219,9$ & $21.446,1$ & $3.450,5$ & $4.033,0$ & $2.277,3$ \\
\hline & & & & & \\
\hline
\end{tabular}


Tabel 4

Pengeluaran Rutin, 1989/1990 - 1996/1997

(dalam nlliar rupiah)

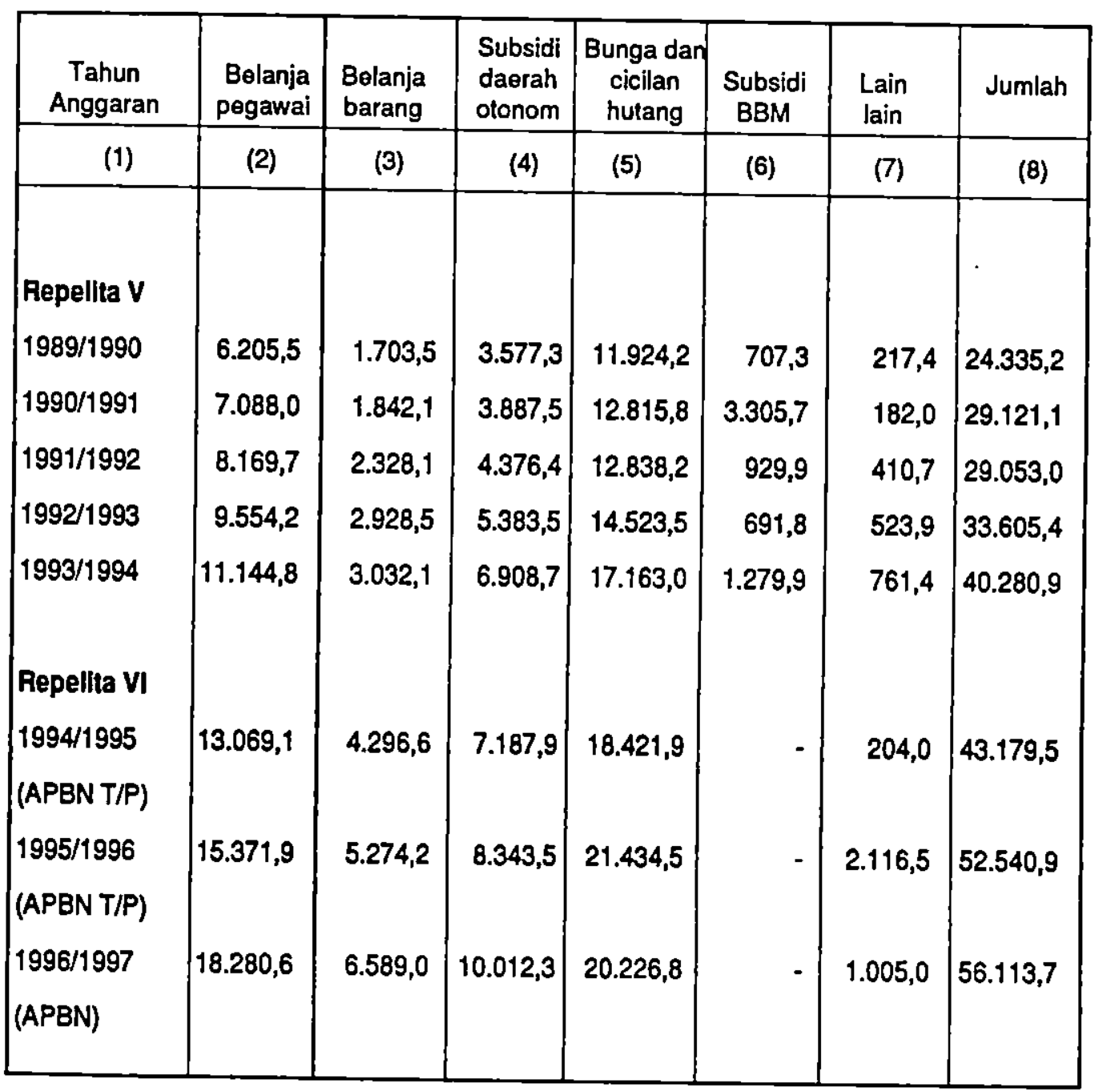


Tabel 5

Sumber-sumber Pemblayaan

Pengeluaran Pembangunan, 1989/1990 - 1996/1997 1)

(dalam nillar rupiah)

\begin{tabular}{|c|c|c|c|c|c|}
\hline \multirow{2}{*}{ Tahun } & \multirow{2}{*}{$\begin{array}{l}\text { Pengeluaran } \\
\text { Pembangunan }\end{array}$} & \multicolumn{4}{|c|}{ Sumber-sumber pembiayaan ${ }^{2)}$} \\
\hline & & $\begin{array}{l}\text { Tabungan } \\
\text { pemerintah }\end{array}$ & $\%$ & $\begin{array}{l}\text { Penerimaan } \\
\text { pembangunan }\end{array}$ & $\%$ \\
\hline (1) & (2) & (3) & (4) & (5) & (6) \\
\hline Repelita V & & & & & - \\
\hline $1989 / 1990$ & $15.393,9$ & $7.169,0$ & 46,3 & $8.330,3$ & 53,7 \\
\hline $1990 / 1991$ & $18.250,8$ & $13.071,9$ & 60,9 & $8.381,5$ & 39,1 \\
\hline 1991/1992 & $23.074,5$ & $13.529,0$ & 57,6 & $9.975,1$ & 42,4 \\
\hline $1992 / 1993$ & $26.906,3$ & $15.257,2$ & 57,9 & $11.097,9$ & 42,1 \\
\hline $1993 / 1994$ & $28.428,1$ & $15.823,2$ & 59,5 & $10.752,5$ & 40,5 \\
\hline Repelita VI & & & & & \\
\hline $\begin{array}{l}1994 / 1995 \\
\text { (APBN T/P) }\end{array}$ & $29.163,3$ & $18.190,4$ & 62,4 & $10.983,2$ & 37,6 \\
\hline $\begin{array}{l}1995 / 1996 \\
\text { (APBN T/P) }\end{array}$ & $29.811,6$ & $19.016,9$ & 63,0 & $11.170,0$ & 37,0 \\
\hline $\begin{array}{l}1996 / 1997 \\
\text { (APBN) }\end{array}$ & $34.502,7$ & $22.089,1$ & 64,0 & $12.413,6$ & 36,0 \\
\hline
\end{tabular}

1) Realisasi PAN

2) Termasuk dalam anggaran lebih (SAI) dalam anggaran kurang (SAK) 
Tabel 6

\section{Pengeluaran Pembangunan DI Luar bantuan Proyek APBN - TP 1995/1996 dan APBN 1996/1997 (dalam nillar rupiah)}

\begin{tabular}{|l|r|r|r|}
\hline \multicolumn{1}{|c|}{ Jenis pengeluaran } & $\begin{array}{r}1995 / 1996 \\
\text { APBN - TP }\end{array}$ & \multicolumn{1}{c|}{$\begin{array}{c}1996 / 1997 \\
\text { APBN }\end{array}$} & \multicolumn{1}{c|}{$\%$} \\
\hline (1) & \multicolumn{1}{c|}{$(2)$} & \multicolumn{1}{c|}{$(3)$} & \multicolumn{1}{c|}{$(4)$} \\
\hline 1. Departemen/Lembaga & $9.667,7$ & $11.954,7$ & 23,7 \\
2. H a n k a m & 760,8 & 767,5 & 0,9 \\
3. Bantuan pembangunan daerah & $5.568,2$ & $6.388,7$ & 14,7 \\
- Inpres desa tertinggal & 484,9 & 478,8 & $-1,1$ \\
- Inpres pembangunan desa & 426,0 & 459,3 & 7,8 \\
- Inpres pembangunan Dati II & $2.517,7$ & $2.905,4$ & 15,4 \\
-Inpres pembangunan Dati I & $1.277,6$ & $1.423,5$ & 11,4 \\
- Inpres sekolah dasar & 498,5 & 595,1 & 19,4 \\
- Inpres kesehatan & 363,5 & 525,6 & 44,6 \\
4. Pembangunan daerah melalui penerimaan PBB & $1.750,9$ & $2.072,3$ & 18,4 \\
5. Subsidi pupuk & 212,4 & 137,0 & $-35,5$ \\
6. Penyertaan modal pemerintah & 79,5 & 55,0 & $-30,8$ \\
7. Lain-lain pembangunan & 602,1 & 713,9 & 18,6 \\
\hline J u m I a h & $18.641,6$ & $22.089,1$ & 18,5 \\
& & & \\
\hline
\end{tabular}

